Article

\title{
Synthesis of Novel Sulfamethaoxazole 4-Thiazolidinone Hybrids and Their Biological Evaluation
}

\author{
Mashooq A. Bhat ${ }^{1, *(\mathbb{D}}$, Mohamed A. Al-Omar ${ }^{1}{ }^{(\mathbb{C}}$, Ahmed M. Naglah $^{2,3} \mathbb{D}^{\mathbb{D}}$ and \\ Azmat Ali Khan ${ }^{1}$ (D) \\ 1 Department of Pharmaceutical Chemistry, College of Pharmacy, King Saud University, Riyadh 11451, \\ Saudi Arabia; malomar1@ksu.edu.sa (M.A.A.-O.); azkhan@ksu.edu.sa (A.A.K.) \\ 2 Department of Pharmaceutical Chemistry, Drug Exploration and Development Chair (DEDC), College of \\ Pharmacy, King Saud University, Riyadh 11451, Saudi Arabia; anaglah@ksu.edu.sa \\ 3 Peptide Chemistry Department, Chemical Industries Research Division, National Research Centre, Dokki, \\ Cairo 12622, Egypt \\ * Correspondence: mabhat@ksu.edu.sa; Tel.: +966-558164097
}

Received: 7 July 2020; Accepted: 31 July 2020; Published: 6 August 2020

\begin{abstract}
A search for potent antitubercular agents prompted us to design and synthesize sulfamethaoxazole incorporated 4-thiazolidinone hybrids (7a-1) by using a cyclocondensation reaction between 4-amino- $N$-(5-methylisoxazol-3-yl)benzenesulfonamide (4), aryl aldehyde (5a-1), and mercapto acetic acid (6) resulting in good to excellent yields. All the newly synthesized 4-thiazolidinone derivatives were screened for their in vitro antitubercular activity against $M$. Bovis $B C G$ and $M$. tuberculosis $H 37 R a(M T B)$ strains. The compounds $\mathbf{7 d}, \mathbf{7 g}, \mathbf{7 i}, \mathbf{7 k}$, and $\mathbf{7 1}$ revealed promising antimycobacterial activity against $M$. Bovis and $M T B$ strains with $\mathrm{IC}_{90}$ values in the range of $0.058-0.22$ and $0.43-5.31 \mu \mathrm{g} / \mathrm{mL}$, respectively. The most active compounds were also evaluated for their cytotoxicity against MCF-7, HCT 116, and A549 cell lines and were found to be non-cytotoxic. Moreover, the synthesized compounds were also analyzed for ADME (absorption, distribution, metabolism, and excretion) properties and showed potential as good oral drug candidates.
\end{abstract}

Keywords: 4-thiazolidinones; sulfamethaoxazole; antimycobacterial activity; cytotoxicity study

\section{Introduction}

Tuberculosis (TB), caused by the pathogen Mycobacterium tuberculosis (MTB) is one of the most infectious causes of mortality worldwide [1]. The pathogenic synergy between TB and HIV is alarming. Moreover, TB frequently occurs in human immunodeficiency virus (HIV)/AIDS patients [2,3]. In 2019, according to the World Health Organization (WHO), 1.5 million deaths were reported due to TB, out of which 0.36 million people were infected with both HIV and TB. Worldwide, the proportion of new cases with multidrug-resistant tuberculosis (MDR-TB) was 3.5\% and has not changed in comparison to recent years [4]. Bacillus Calmette-Guerin (BCG) is an attenuated derivative of a virulent strain of Mycobacterium bovis which has been used as a vaccine against MTB, as a recombinant vehicle for multivalent vaccines against other infectious diseases, and as cancer immunotherapy [5]. Therefore, the ability to rapidly and specifically identify BCG is clinically important. In addition to this, totally drug-resistant TB (TDR-TB) has recently arisen which is resistant to all clinical drugs [6]. Delamanid (OPC-67683) and Bedaquiline (TMC207) are the two drugs recommended by the US FDA for multi-drug-resistant tuberculosis (MDR-TB) treatment $[7,8]$. However, at present there are no medicinal drugs under clinical trials. Because of this, there is an urgent need for novel, safe, and effective antimycobacterial drugs which will efficiently treat XDR and MDR tuberculosis. 
Numerous heterocyclic compounds containing nitrogen, sulfur, and oxygen heteroatoms have attracted the attention of chemists over the years because of their biological properties. In particular, the thiazolidin-4-ones, a privileged pharmacophore possesses an array of biological activities including anti-inflammatory [9], antimicrobial [10], antibiofilm [11], antiparasitic [12], anticancer [13], anti-viral [14], antidiabetic [15], antiarthritic [16], FSH agonist [17], JNK stimulating phosphatase-1 (JSP-1) [18], CNS-penetrant [19], CDK1/Cyclin B inhibition [20], COX-2 inhibitor [21] and hypoglycemia [22] properties. In the last few years, Kucukguzel et al. developed substituted 4-thiazolidinones and among them compounds 1 and $\mathbf{4}$ exhibited excellent antitubercular activity with $90 \%$ and $98 \%$ inhibitions at $6.25 \mu \mathrm{g} / \mathrm{mL}$, respectively [23]. Jaju and co-workers reported antitubercular activity of isonicotinyl hydrazide derivatives against $M$. tuberculosis $H 37 R v$ strain. Among the synthesized isonicotinylhydrazide derivatives compound 3 was found to be more active with MIC $=0.31 \mu \mathrm{g} / \mathrm{mL}$ [24]. Recently, compounds 2, 5, and 6 bearing 4-thiazolidinone scaffolds were reported for their excellent antitubercular activities [25-30]. Some representative biologically active 4-thiazolidinones are shown in Figure 1.

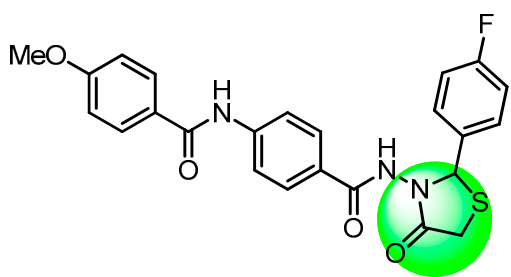

1

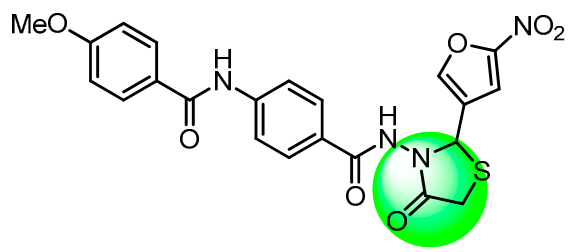

4

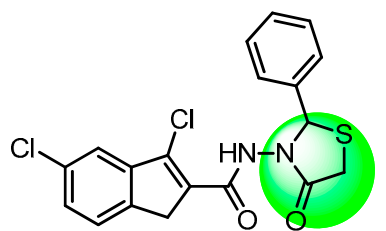

2



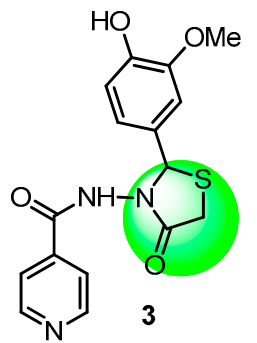

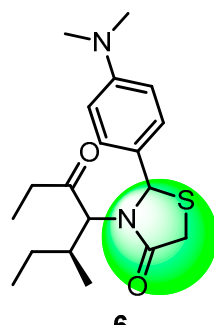

6

Figure 1. 4-Thiazolidinone scaffolds showing antimycobacterial activity.

A literature survey revealed that sulfonamide derivatives are endowed with numerous therapeutic activities as anticonvulsants, HIV protease inhibitors, and antitumor agents [31]. Sulfonamide derivatives are also used for treating certain forms of malaria, urinary tract infections, erectile dysfunction [32] as well as use as herbicides and dyes [33]. Isoxazole derivatives also possess various interesting pharmacological properties. 5-methylisoxazole is present in many marketed drugs such as Valdecoxib, Parecoxib, and Leflunomide and exhibits broad spectrum activity such as anticancer, antiviral, antibacterial, analgesic, anticonvulsant, antinociceptive, and immunomodulating activities [34].

The design of sulfamethaoxazole 4-thiazolidinone hybrids requires the consideration of three different parts, as depicted in Figure 2. The 4-thiazolidinone motif is the main backbone of the design strategy. It helps to enhance the pharmacophoric properties of the synthesized compounds [35]. The second segment is the sulfonamide unit linked to the isoxazole nucleus which is responsible for the biological activity. Sulfonamides and isoxazole scaffolds are present in many reported drugs such as Celecoxib and Parecoxib. Last of the all, the aryl ring with the diverse substitutional unit, is responsible for the lipophilicity control while contributing as a highly potent pharmacological part due to the existence of various functional groups. 


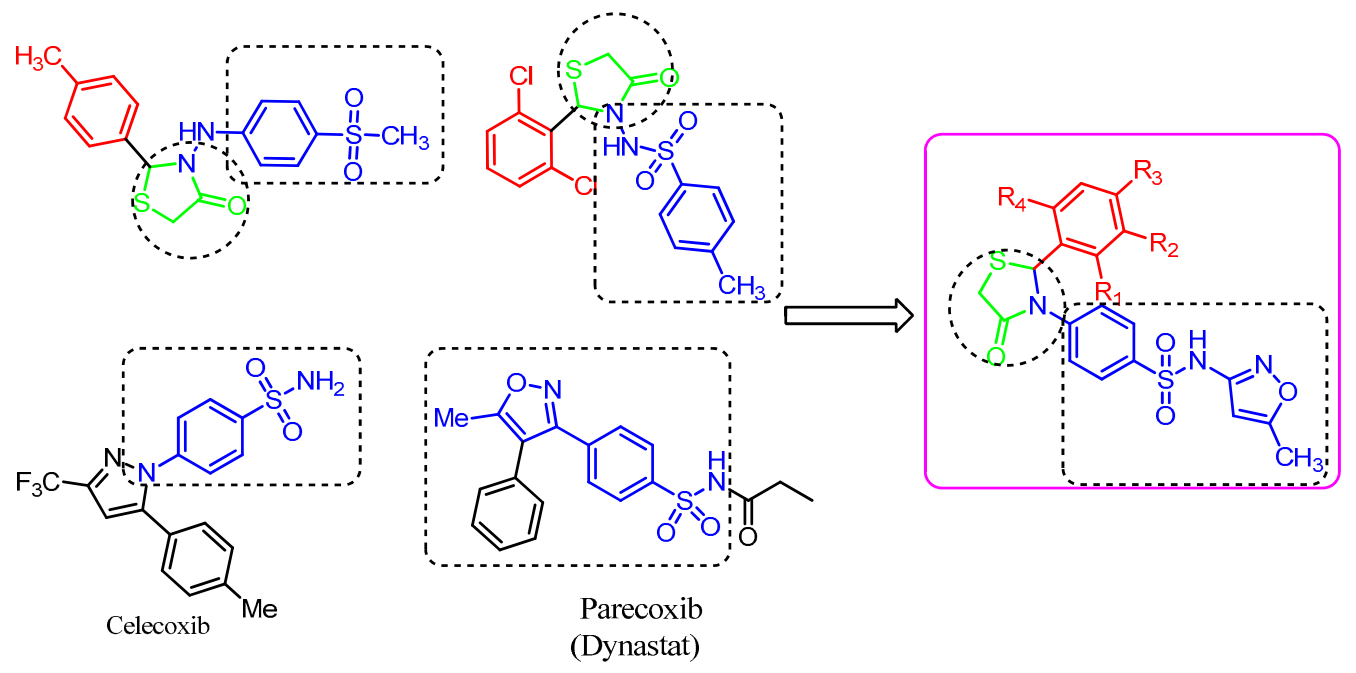

Figure 2. Molecular design of the target molecule.

According to the pharmacological importance of the above reported compounds and in continuation of our efforts based on the design, synthesis and biological evaluation of heterocyclic derivatives [36,37], we designed and synthesized 4-thiazolidinone hybrids by assembling, in a single molecular framework, sulfonamides and isoxazole units, with the aim to obtain prominent antimycobacterial activity with minimal side effects.

\section{Results and Discussion}

The protocol for the syntheses of a series of new sulfamethaoxazole 4-thiazolidinone hybrids $(7 \mathbf{a}-1)$ is reported in Schemes 1 and 2. Compounds $(7 \mathbf{a}-1)$ were prepared from a cyclocondensation reaction between 4-amino- $N$-(5-methylisoxazol-3-yl)benzenesulfonamide (4), aryl aldehydes (5a-1), and mercapto acetic acid (6) (Scheme 2).

The required starting materials, 4-amino- $N$-(5-methylisoxazol-3-yl)benzenesulfonamide (4) were prepared from commercially available $\mathrm{N}$-acetylsulfanilyl chloride (1) and 3-amino-5-methylisoxazole (2) to give the $\mathrm{N}$-acylated intermediate (3) followed by acid hydrolysis [38] and details as depicted in (Scheme 1). The synthesis of new sulfamethaoxazole-incorporated 4-thiazolidinone hybrids (7a-1) was achieved via a cyclocondensation reaction between 4-amino- $N$-(5-methylisoxazol-3-yl) benzenesulfonamide (4), aryl aldehydes (5a-1), and mercapto acetic acid (3) in toluene at reflux temperature for $2 \mathrm{~h}$ (Scheme 2).

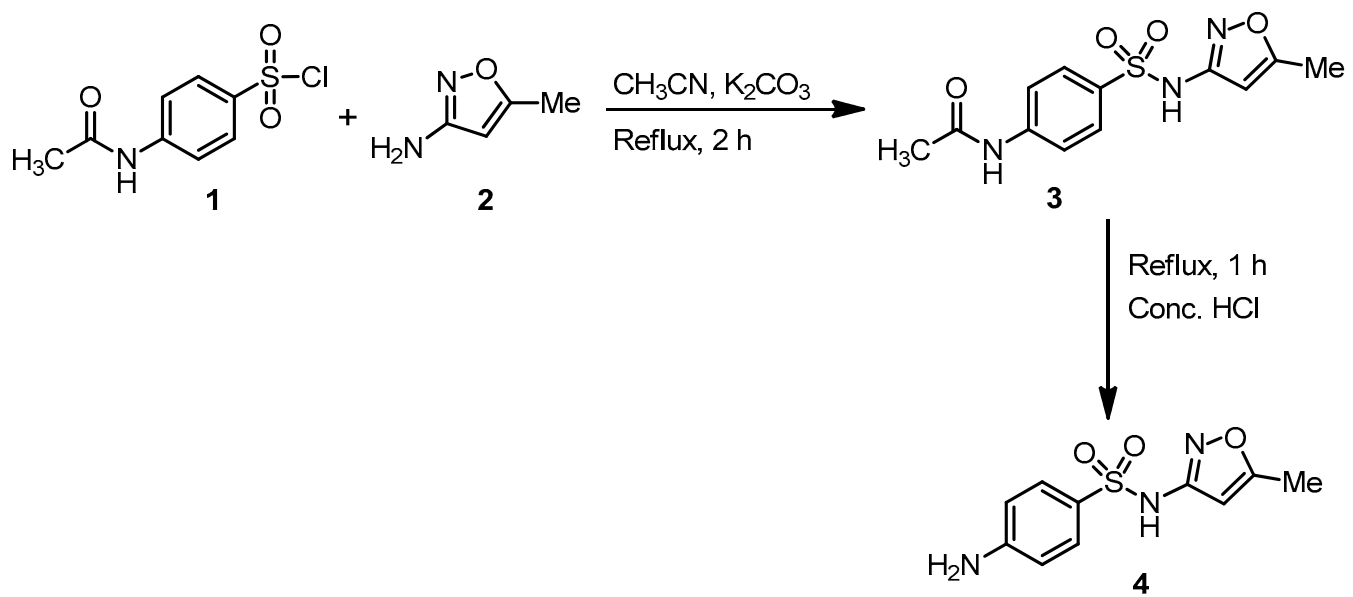

Scheme 1. Synthesis of 4-amino- $N$-(5-methylisoxazol-3-yl)benzenesulfonamide (4). 


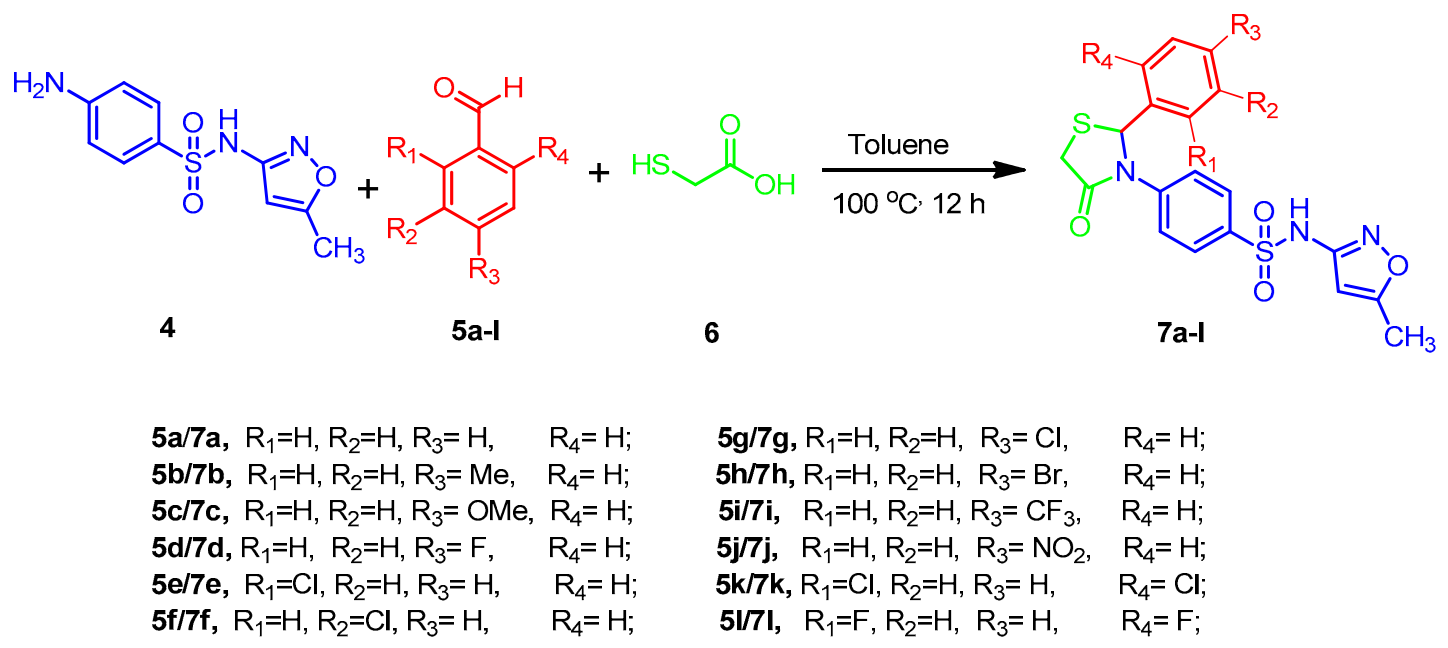

Scheme 2. Synthesis of sulfamethaoxazole 4-thiazolidinone hybrids (7a-1).

All the newly synthesized compounds were characterized by ${ }^{1} \mathrm{H}$ NMR, ${ }^{13} \mathrm{C}$ NMR and HRMS techniques. The ${ }^{1} \mathrm{H}$ NMR spectrum of compound $7 \mathbf{a}$, the methylene protons of the 4 -thiazolidinone ring appeared as two distinct doublet of doublets at $\delta 3.76$ and $3.72 \mathrm{ppm}$, indicating that both the protons were magnetically non-equivalent. The $\mathrm{C}-\mathrm{H}$ proton of the 4 -thiazolidinone ring appeared as a singlet at $\delta 6.71 \mathrm{ppm}$. The formation of the 4-thiazolidinone ring was also proven by the appearance of peaks at $33.04\left(\mathrm{CH}_{2}\right), 68.44(\mathrm{CH})$, and $179.2(\mathrm{C}=\mathrm{O}) \mathrm{ppm}$, respectively in the ${ }^{13} \mathrm{C} \mathrm{NMR}$ spectrum of compound $7 \mathbf{a}$. The HRMS spectrum further strengthened the structure assigned to $(7 \mathbf{a})$ as $N$-(5-methylisoxazol-3-yl)-4-(4-oxo-2-phenylthiazolidin-3-yl)benzenesulfonamide, showing $[\mathrm{M}+\mathrm{H}]^{+}$ ion peak at $m / z 416.2147$ for its molecular formula $\mathrm{C}_{19} \mathrm{H}_{18} \mathrm{~N}_{3} \mathrm{O}_{4} \mathrm{~S}$. Experimental procedures and spectra of 4 -thiazolidinone derivatives (7a-1) are given in the Supplementary Materials. The synthetic sequence is depicted in Scheme 1.

\subsection{Anti-Mycobacterial Activity}

The newly synthesized sulfamethaoxazole 4-thiazolidinone hybrids (7a-1) were screened for in vitro antitubercular activity against $M$. Bovis BCG (ATCC 35743) and MTB H37Ra (ATCC 25177) in liquid medium [39]. We explored the eminent XTT Reduction Menadione assay (XRMA) of the anti-mycobacterial screening protocol employing first-line anti-mycobacterial rifampicin drug as a standard reference and the $\mathrm{IC}_{50}$ and $\mathrm{IC}_{90}$ values are presented in Table 1.

The sulfamethaoxazole 4-thiazolidinone derivatives $\mathbf{7 d}, \mathbf{7 g}, \mathbf{7 i}, \mathbf{7 k}$, and $7 \mathbf{l}$ exhibited excellent antitubercular activities with $\mathrm{IC}_{90}$ values ranging from $0.058-0.22$ and $0.43-5.31 \mu \mathrm{g} / \mathrm{mL}$. They are found to be most active against M. bovis BCG and MTB H37Ra and strain, respectively. However, the rest of the derivatives $\mathbf{7 a}, \mathbf{7 b}, \mathbf{7}, \mathbf{c}, \mathbf{7 e}, \mathbf{7 f}, \mathbf{7} \mathbf{h}$ and $\mathbf{7 j}$ were found to be less active against $M$. bovis $B C G$ and MTB H37Ra strain with $\mathrm{IC}_{90}=>30 \mu \mathrm{g} / \mathrm{mL}$.

\subsection{Structure Activity Relationship (SAR)}

According to the in vitro data, the sulfamethaoxazole incorporated 4-thiazolidinone hybrids displayed significant anti-mycobacterial activity and the results are presented in Table 1 . The hybrid molecules derived from 4-amino- $N$-(5-methylisoxazol-3-yl) benzenesulfonamide, aryl aldehydes, and mercapto acetic acid have been used as a basic skeleton for the development of structural analogues, which produced the sulfamethaoxazole incorporated 4 -thiazolidinone derivatives (7a-1). The results of the biological evaluation revealed that the activity was considerably affected by introducing various substituents on the aryl ring. 
Table 1. Anti-mycobacterial activity of the sulfamethaoxazole incorporated 4-thiazolidinones ${ }^{\text {a }}$.

\begin{tabular}{|c|c|c|c|c|c|}
\hline \multirow{2}{*}{ Entry } & \multirow{2}{*}{ Structures } & \multicolumn{2}{|c|}{ M. Bovis BCG } & \multicolumn{2}{|c|}{ MTBH37Ra } \\
\hline & & $\mathrm{IC}_{50}$ & $\mathrm{IC}_{90}$ & $\mathrm{IC}_{50}$ & $\mathrm{IC}_{90}$ \\
\hline $7 a$ & & $>30$ & $>30$ & $>30$ & $>30$ \\
\hline $7 \mathrm{~b}$ & & $>30$ & $>30$ & $>30$ & $>30$ \\
\hline $7 \mathrm{c}$ & & $>30$ & $>30$ & $>30$ & $>30$ \\
\hline $7 d$ & & 0.03 & 0.22 & 0.54 & 0.70 \\
\hline
\end{tabular}


Table 1. Cont.

\begin{tabular}{|c|c|c|c|c|c|}
\hline \multirow{2}{*}{ Entry } & \multirow{2}{*}{ Structures } & \multicolumn{2}{|c|}{ M. Bovis BCG } & \multicolumn{2}{|c|}{ MTВH37Ra } \\
\hline & & $\mathrm{IC}_{50}$ & $\mathrm{IC}_{90}$ & $\mathrm{IC}_{50}$ & $\mathrm{IC}_{90}$ \\
\hline $7 e$ & & 2.86 & $>30$ & 1.26 & $>30$ \\
\hline $7 f$ & & 16.75 & $>30$ & 1.68 & $>30$ \\
\hline $7 \mathrm{~g}$ & & 0.02 & 0.13 & 0.12 & 5.31 \\
\hline $7 \mathrm{~h}$ & & $>30$ & $>30$ & $>30$ & $>30$ \\
\hline
\end{tabular}


Table 1. Cont.

\begin{tabular}{|c|c|c|c|c|c|}
\hline \multirow{2}{*}{ Entry } & \multirow{2}{*}{ Structures } & \multicolumn{2}{|c|}{ M. Bovis BCG } & \multicolumn{2}{|c|}{ MTBH37Ra } \\
\hline & & $\mathrm{IC}_{50}$ & $\mathrm{IC}_{90}$ & $\mathrm{IC}_{50}$ & $\mathrm{IC}_{90}$ \\
\hline $7 \mathbf{i}$ & & 0.28 & 0.17 & 0.16 & 1.08 \\
\hline $7 \mathbf{j}$ & & $>30$ & $>30$ & $>30$ & $>30$ \\
\hline $7 k$ & & 0.026 & 0.15 & 0.13 & 0.71 \\
\hline 71 & & 0.016 & 0.058 & 0.07 & 0.43 \\
\hline $\mathbf{b}_{\mathbf{R P}}$ & & $0.0043 \pm 0.00028$ & $0.0173 \pm 0.039$ & $0.0019 \pm 0.00022$ & $0.020 \pm 0.0021$ \\
\hline
\end{tabular}

$\overline{\mathrm{a}^{\mathrm{I}} \mathrm{IC}_{50} / \mathrm{IC}} \mathrm{C}_{90}$ in $\mu \mathrm{g} / \mathrm{mL}$. Anti-mycobacterial activity of each agent was determined by serial dose dependent dilutions. ${ }^{\mathrm{b}}$ Rifampicin as a standard reference antitubercular drug and positive control. 
Firstly, we discuss the anti-mycobacterial activity of synthesized compounds against $M$. Bovis BCG strain. From the series (7a-1), compound 7a without any substituent on the aryl ring displays lesser potency with $\mathrm{IC}_{90}$ value $>30 \mu \mathrm{g} / \mathrm{mL}$ against $M$. Bovis BCG strains as compared to the standard drug rifampicin and the results are displayed in Table 1 . Compounds $7 \mathbf{b}$ in which $\left(\mathrm{R}_{3}=-m e t h y l\right)$ and $7 \mathbf{c}$ in which $\left(\mathrm{R}_{3}=-\right.$ methoxy) showed lower antitubercular activity against $M$. Bovis BCG strain with $\mathrm{IC}_{90}$ values $>30 \mu \mathrm{g} / \mathrm{mL}$. The introduction of the fluoro group in compound $\mathbf{7 d}\left(\mathrm{R}_{3}=-\right.$ fluoro $)$ presented excellent antitubercular activity against $M$. Bovis BCG strain with $\mathrm{IC}_{90}$ value $0.22 \mu \mathrm{g} / \mathrm{mL}$. Introduction of the chloro group in the aryl ring of compound $7 \mathbf{e}\left(\mathrm{R}_{1}=-\right.$ chloro $)$ and $7 \mathbf{f}\left(\mathrm{R}_{2}=-\right.$ chloro $)$ showed lesser potency against $M$. Bovis $B C G$ strain with $\mathrm{IC}_{90}$ value $>30 \mu \mathrm{g} / \mathrm{mL}$. With a chloro group in the $\mathrm{R}_{3}$ position in compound $\mathbf{7 g}\left(\mathrm{R}_{3}=-\right.$ chloro $)$ it was highly potent against $M$. Bovis BCG strain with an $\mathrm{IC}_{90}$ value $0.13 \mu \mathrm{g} / \mathrm{mL}$.

Replacing the chloro group by a bromo group $7 \mathbf{h}\left(\mathrm{R}_{3}=-\right.$ bromo $)$ exhibits less activity towards M. Bovis $B C G$ strain with $\mathrm{IC}_{90}$ value $>30 \mu \mathrm{g} / \mathrm{mL}$. Introduction of a $\mathrm{CF}_{3}$ group at the para position of the aryl group $7 \mathbf{i}\left(\mathrm{R}_{3}=-C F_{3}\right)$ compound displays excellent antitubercular effect against $M$. Bovis BCG with $0.17 \mu \mathrm{g} / \mathrm{mL}$. With the introduction of a nitro group at the para position $7 \mathbf{j}\left(\mathrm{R}_{3}=-\mathrm{NO}_{2}\right)$ the compound does not show any antitubercular activity against the $M$. Bovis BCG strain. In compounds 7k $\left(\mathrm{R}_{1}=\mathrm{R}_{4}=-\right.$ fluoro $)$ the compound showed a sharp increase in antitubercular activity against the M. Bovis BCG strain with $0.15 \mu \mathrm{g} / \mathrm{mL}$. With the disubstituted compound $71\left(\mathrm{R}_{1}=\mathrm{R}_{4}=-\right.$ chloro $)$ it showed an increase in antitubercular activity with $\mathrm{IC}_{90}$ value $0.058 \mu \mathrm{g} / \mathrm{mL}$ against $M$. Bovis BCG strain. Hence, among all the newly synthesized compounds (7a-1), compounds $\mathbf{7 d}, \mathbf{7 g}, \mathbf{7 i}, \mathbf{7 k}$, and $\mathbf{7 1}$, exhibit promising anti-mycobacterial activity against $M$. Bovis BCG and the results are summarized in Table 1.

Now, we also screened the antitubercular activity against the $M T B H 37 R a$ strain. From the 4-thiazolidinone series (7a-1), compound 7a without any substitution on the aryl ring showed lower anti-mycobacterial activity with $\mathrm{IC}_{90}$ value $>30 \mu \mathrm{g} / \mathrm{mL}$ against $M T B H 37 R a$ strain and the results are shown in Table 1 . Compounds $7 \mathbf{b}$ in which $\left(\mathrm{R}_{3}=-\right.$ methyl) and $7 \mathbf{c}$ in which $\left(\mathrm{R}_{3}=-\right.$ methoxy) showed lower activity against $M T B H 37 R a$ strain with $\mathrm{IC}_{90}$ values $>30 \mu \mathrm{g} / \mathrm{mL}$. With the introduction of the fluoro group, compound $\mathbf{7 d}\left(\mathrm{R}_{3}=-\right.$ fluoro $)$ showed prominent activity against $M T B H 37 R a$ strain with IC 90 value of $0.70 \mu \mathrm{g} / \mathrm{mL}$.

Introduction of the chloro group in the aryl ring of compound $7 \mathbf{e}\left(\mathrm{R}_{1}=-\right.$ chloro $)$ and $\mathbf{7 f}\left(\mathrm{R}_{2}=-\right.$ chloro $)$ resulted in them exhibiting less potency against the $M T B H 37 R a$ strain with $\mathrm{IC}_{90}$ value $>30 \mu \mathrm{g} / \mathrm{mL}$. With a chloro group in $\mathrm{R}_{3}$ position in compound $7 \mathrm{~g}\left(\mathrm{R}_{3}=-\right.$ chloro $)$, it results surprisingly with an increase in antitubercular activity against $M T B H 37 R a$ strain with $\mathrm{IC}_{90}$ value $5.31 \mu \mathrm{g} / \mathrm{mL}$. Replacing the chloro group by a bromo group $7 \mathrm{~h}\left(\mathrm{R}_{3}=-\right.$ bromo $)$ results in lower activity with $\mathrm{IC}_{90}$ value $>30 \mu \mathrm{g} / \mathrm{mL}$ against MTB H37Ra strain. Introduction of a $\mathrm{CF}_{3}$ group at the para position of the aryl group $7 \mathbf{i}\left(\mathrm{R}_{3}=-C F_{3}\right)$ exhibits promising antitubercular against $M T B H 37 R a$ with $\mathrm{IC}_{90}$ value $1.08 \mu \mathrm{g} / \mathrm{mL}$. Introduction of the nitro group at the para position $7 \mathbf{j}\left(\mathrm{R}_{3}=-\mathrm{NO}_{2}\right)$ does not show any anti-mycobacterial activity against the MTB H37Ra strain. With disubstituted compounds $7 \mathbf{k}\left(\mathrm{R}_{1}=\mathrm{R}_{4}=-\right.$ fluoro $)$ there is displayed excellent activity against the $M T B H 37 R a$ strain with $0.71 \mu \mathrm{g} / \mathrm{mL}$. Compounds $71\left(\mathrm{R}_{1}=\mathrm{R}_{4}=-\right.$ chloro $)$ show promising anti-mycobacterial activity with $\mathrm{IC}_{90}$ value $0.43 \mu \mathrm{g} / \mathrm{mL}$ against MTB H37Ra strain. Hence, among all the synthesized compounds $\mathbf{7 a - 1}$, compounds $\mathbf{7 d}, \mathbf{7 g}, \mathbf{7} \mathbf{i}, \mathbf{7 k}$, and $\mathbf{7 1}$ showed excellent antitubercular activity against MTB H37Ra and the results are displayed in Table 1.

\subsection{Cytotoxicity}

The highly active sulfamethaoxazole incorporated 4-thiazolidinones $\mathbf{7 d}, \mathbf{7 g}, \mathbf{7 i}, \mathbf{7 k}$, and $7 \mathbf{l}$ were tested for cytotoxicity activity against three human cancer cell lines MCF-7, HCT 116, and A549 using the well established MTT protocol [40]. The cytotoxicity results of these compounds indicate they are highly potent and are specific inhibitors against $M$. Bovis BCG and MTB H37Ra strain with $\mathrm{GI}_{50} / \mathrm{GI}_{90}$ $(>100 \mu \mathrm{g} / \mathrm{mL})$. Thus, all the most active compounds were relatively non-toxic against MCF-7, HCT 116 and $\mathrm{A} 549$ cell lines with $\left(\mathrm{GI}_{50} / \mathrm{GI}_{90}\right)$ of $>100$ and the results are incorporated in Table 2. 
Table 2. In vitro cytotoxicity of selected 4-thiazolidinone derivatives.

\begin{tabular}{|c|c|c|c|c|c|c|}
\hline \multirow[t]{2}{*}{ Entry } & \multicolumn{2}{|c|}{$\begin{array}{l}\text { MCF-7 (Breast) } \\
\text { Cell Line }\end{array}$} & \multicolumn{2}{|c|}{$\begin{array}{c}\text { HCT } 116 \text { (Colorectal) } \\
\text { Cell Line }\end{array}$} & \multicolumn{2}{|c|}{$\begin{array}{l}\text { A549 (Lung) } \\
\text { Cell Line }\end{array}$} \\
\hline & $\mathrm{GI}_{50}(\mu \mathrm{g} / \mathrm{mL})$ & $\mathrm{GI}_{90}(\mu \mathrm{g} / \mathrm{mL})$ & $\mathrm{GI}_{50}(\mu \mathrm{g} / \mathrm{mL})$ & $\mathrm{GI}_{90}(\mu \mathrm{g} / \mathrm{mL})$ & $\mathrm{GI}_{50}(\mu \mathrm{g} / \mathrm{mL})$ & $\mathrm{GI}_{90}(\mu \mathrm{g} / \mathrm{mL})$ \\
\hline $7 d$ & $>100$ & $>100$ & $>100$ & $>100$ & $>100$ & $>100$ \\
\hline $7 g$ & $>100$ & $>100$ & $>100$ & $>100$ & $>100$ & $>100$ \\
\hline $7 \mathbf{i}$ & $>100$ & $>100$ & $>100$ & $>100$ & $>100$ & $>100$ \\
\hline $7 \mathbf{k}$ & $>100$ & $>100$ & $>100$ & $>100$ & $>100$ & $>100$ \\
\hline 71 & $>100$ & $>100$ & $>100$ & $>100$ & $>100$ & $>100$ \\
\hline Paclitaxel & 0.0048 & 0.075 & 0.1279 & 5.715 & 0.0035 & 0.0706 \\
\hline Rifampicin & $>100$ & $>100$ & $>100$ & $>100$ & $>100$ & $>100$ \\
\hline
\end{tabular}

\subsection{Selectivity Index (SI)}

The selectivity index indicates that a highly potent compound is only active against mycobacteria but it is non-toxic against host human cell lines. According to a study on the drug susceptibility of TB, antitubercular activity was considered to be specific when the selectivity index was $>10$ [41]. This study suggested that, compounds $\mathbf{7 d}, \mathbf{7 g}, \mathbf{7} \mathbf{i}, \mathbf{7 k}$, and $7 \mathbf{l}$ display the highest selectivity index $>10$, suggesting that these compounds act as highly potent antimycobacterial agents and should be modified for the next level. The selectivity index study results are incorporated in Table 3.

Table 3. Selectivity index against dormant M. bovis BCG and MTB H37Ra.

\begin{tabular}{ccccccc}
\hline \multirow{2}{*}{ Entry } & \multicolumn{2}{c}{ MCF-7 } & \multicolumn{2}{c}{ HCT 116 } & \multicolumn{2}{c}{ A549 } \\
\cline { 2 - 6 } & MTB H37Ra & M. Bovis BCG & MTB H37Ra & M. Bovis BCG & MTB H37Ra & M. Bovis BCG \\
\hline 7d & 139.1 & 476.1 & 139.1 & 476.1 & 139.1 & 476.1 \\
7g & 94.5 & 832.9 & 94.5 & 832.9 & 94.5 & 833.9 \\
7i & 19.1 & 587.9 & 19.1 & 587.9 & 19.1 & 587.9 \\
$7 \mathbf{7 k}$ & 143.1 & 667.1 & 143.1 & 667.1 & 143.1 & 667.1 \\
7l & 237.8 & 12.1 & 237.8 & 12.1 & 237.8 & 12.1 \\
Rifampicin & $>5000$ & 1754.4 & $>5000$ & 1754.4 & $>5000$ & 1754.4 \\
\hline
\end{tabular}

\subsection{Antibacterial Activity}

To determine the specificity of the most potent compounds $\mathbf{7 d}, \mathbf{7 g}, \mathbf{7 i}, \mathbf{7 k}$, and $\mathbf{7 l}$ were evaluated for their antibacterial activity against Gram-negative bacteria (P. flurescense ATCC 13525), (E. coli ATCC 25292) and Gram-positive bacteria (B. subtillus ATCC 23857), (S. aureus ATCC 29213). The antibacterial activity protocol suggests that all the active compounds were much less active towards bacterial strains. All the most active compounds exhibited higher specificity towards M. Bovis BCG and MTB H37Ra strains (Table 4).

Table 4. Antibacterial activity $\mathrm{IC}_{90}(\mu \mathrm{g} / \mathrm{mL})$.

\begin{tabular}{ccccc}
\hline Entry & P. fluorescens & E. coli & B. subtillus & S. aureus \\
\hline $\mathbf{7 d}$ & $>100$ & $>100$ & $>100$ & $>100$ \\
$\mathbf{7 g}$ & $>100$ & $>100$ & $>100$ & $>100$ \\
$\mathbf{7 i}$ & $>100$ & $>100$ & $>100$ & $>100$ \\
$7 \mathbf{k}$ & $>100$ & $>100$ & $>100$ & $>100$ \\
$\mathbf{7 l}$ & $>100$ & $>100$ & $>100$ & $>100$ \\
Ampicillin & 4.36 & 1.46 & 10.32 & 1 \\
Kanamycin & 0.49 & 1.62 & 1.35 & $>30$ \\
\hline
\end{tabular}

\subsection{ADME Properties}

The success of a drug is determined not only by good efficacy but also by an acceptable ADME profile. In this study, we calculated the molecular volume (MV), the molecular weight (MW), 
the logarithm of partition coefficient (miLog $P$ ), the number of hydrogen bond acceptors (n-ON), the number of hydrogen bonds donors (n-OHNH), the topological polar surface area (TPSA), the number of rotatable bonds (n-ROTB) and Lipinski's rule of five [42] using the Molinspiration online property calculation tool kit [43]. Absorption (\%ABS) was calculated by: \%ABS $=109-(0.345 \times$ TPSA) [44].

The drug-likeness model score (a collective property of physico-chemical properties, pharmacokinetics, and pharmacodynamics of a compound, represented by a numerical value) was computed by MolSoft software [45]. A computational study of all the synthesized compounds was performed for prediction of the ADME properties and the values obtained are presented in Table 4. It is apparent that the compounds exhibited a good \%ABS (\%absorption) ranging from 69.11 to $85.02 \%$.

Furthermore, the compounds $\mathbf{7 d}, \mathbf{7 g}, \mathbf{7} \mathbf{i}, \mathbf{7 k}$, and $\mathbf{7 l}$ did not violate Lipinski's rule of five $(\operatorname{miLog} P \leq 5)$ and results are incorporated in Table 5. A molecule likely to be developed as an orally active drug candidate should show no more than one violation of the following four criteria: miLog $P$ (octanol-water partition coefficient) $\leq 5$, molecular weight $\leq 500$, number of hydrogen bond acceptors $\leq 10$, and number of hydrogen bond donors $\leq 5$ [46]. The larger the value of the drug likeness model score, the higher is also the probability that the particular molecule will be active. All the tested compounds followed the criteria for orally active drugs and therefore, these compounds may have a good potential for eventual development as oral agents.

According to the literature survey, it was found that these type of compounds can bind to the matrix metalloproteinase-8 (MMP-8; also known as neutrophil collagenase; PDB ID: 5h8x) [47,48]. This endopeptidase is part of a complex proteolytic MMP enzyme family, where its over expression has been linked to several pathological processes [48]. As several articles had already described the coordination of metals by sulfur containing compounds $[49,50]$, we investigated whether the sulfamethaoxazole in our compounds could coordinate the $\mathrm{Zn}^{2+}$ ion in MMP-8. This could promote potential inhibitory activity on MMP-8, as presented by Tauro et al. [48]. According to previous reports of molecular docking studies our target compounds should easily coordinate the $\mathrm{Zn}^{2+}$ in the receptor cavity. The interactions of the sulfamethaoxazole moiety was identical to the interactions observed in the original catechol ligand (hydrogen bonds with backbones of Ala161 and Leu160). 
Table 5. Pharmacokinetic parameters important for good oral bioavailability and the drug likeness model scores.

\begin{tabular}{|c|c|c|c|c|c|c|c|c|c|c|}
\hline Com. & $\%$ ABS & TPSA $\left(A^{2}\right)$ & n-ROTB & MV & MW & $\operatorname{miLog} P$ & $\mathrm{n}-\mathrm{ON}$ & n-OHNH & Lipinski Violation & \multirow{2}{*}{ Drug Likeness Model Score } \\
\hline Rule & - & - & - & - & $<500$ & $\leq 5$ & $<10$ & $<5$ & $\leq 1$ & \\
\hline $7 a$ & 77.08 & 92.51 & 5 & 337.35 & 415.50 & 2.91 & 7 & 1 & 0 & -0.10 \\
\hline $7 \mathrm{~b}$ & 77.08 & 92.51 & 5 & 353.91 & 429.52 & 3.36 & 7 & 1 & 0 & -0.27 \\
\hline $7 c$ & 73.89 & 101.74 & 6 & 362.90 & 445.52 & 2.97 & 8 & 1 & 0 & 0.01 \\
\hline $7 d$ & 77.08 & 92.51 & 5 & 342.28 & 433.19 & 3.08 & 7 & 1 & 0 & 0.21 \\
\hline $7 e$ & 77.08 & 92.51 & 5 & 350.89 & 449.94 & 3.54 & 7 & 1 & 0 & 0.01 \\
\hline $7 \mathrm{f}$ & 77.08 & 92.51 & 5 & 350.89 & 449.94 & 3.57 & 7 & 1 & 0 & 0.10 \\
\hline $7 \mathrm{~g}$ & 77.08 & 92.51 & 5 & 350.89 & 449.94 & 3.59 & 7 & 1 & 0 & 0.36 \\
\hline $7 \mathrm{~h}$ & 77.08 & 92.51 & 5 & 353.24 & 494.39 & 3.72 & 7 & 1 & 0 & -0.02 \\
\hline $7 \mathbf{i}$ & 77.08 & 92.51 & 6 & 368.65 & 483.49 & 3.81 & 7 & 1 & 0 & -0.17 \\
\hline $7 \mathbf{j}$ & 61.31 & 138.23 & 6 & 360.69 & 460.49 & 2.87 & 10 & 1 & 0 & -0.12 \\
\hline $7 \mathrm{k}$ & 77.08 & 92.51 & 5 & 347.21 & 451.48 & 3.14 & 7 & 1 & 0 & -0.20 \\
\hline 71 & 77.08 & 92.51 & 5 & 364.42 & 484.39 & 4.17 & 7 & 1 & 0 & -0.04 \\
\hline
\end{tabular}

Com: Compound, \%ABS: percentage absorption, TPSA: topological polar surface area, n-ROTB: number of rotatable bonds, MV: molecular volume, MW: molecular weight, miLog $P$ : logarithm of partition coefficient of compound between n-octanol and water, $\mathrm{n}$-ON acceptors: number of hydrogen bond acceptors, $\mathrm{n}$-OHNH donors: number of hydrogen bonds donors. 


\section{Materials and Methods}

\subsection{Materials}

All the solvents and regents were purchased from Sigma Aldrich (Gillingham, UK) and they were used in the reactions without purification. The progress of each reaction was monitored by ascending thin layer chromatography (TLC) using TLC aluminum sheets, silica gel $60 \mathrm{~F}_{254}$ precoated (Merck, Darmstadt, Germany), and locating the spots using UV light as the visualizing agent or iodine vapor. The melting points for the 4-thiazolidinone conjugates were carried out using an open capillary method and they are uncorrected. ${ }^{1} \mathrm{H}$ NMR spectra were obtained on a Bruker DRX-400 MHz NMR spectrometer in DMSO- $d_{6}$ ( $\delta$ in ppm relative to tetramethylsilane (TMS) as an internal standard) and ${ }^{13} \mathrm{C}$ NMR spectra were recorded (DMSO- $d_{6}$ ) on a Bruker DRX-100 MHz spectrometer (Bruker BioSpin MRI GmbH, Ettlingen, Germany). High-resolution mass spectra (HRMS) were obtained using an Agilent 6520 (QTOF) ESI-HRMS model (Thermo Fisher Scientific, Waltham, MA, USA).

\subsection{Typical Experimental Procedure for the Synthesis of 4-Amino-N-(5-methylisoxazol-3-yl)benzenesulfonamide (4)}

A mixture of $N$-acetylsulfanilyl chloride (1) (10 mmol), 3-amino-5-methylisoxazole (2) (10 mmol), and $\mathrm{K}_{2} \mathrm{CO}_{3}(5 \mathrm{mmol})$ was dissolved in acetonitrile $(30 \mathrm{~mL})$. The reaction mass was refluxed for $2 \mathrm{~h}$ to give the $N$-acylation intermediate (3) followed by acid hydrolysis. The progress of the reaction was monitored by using TLC. After $3 \mathrm{~h}$, the reaction mass was poured into ice cold water. The obtained solid was filtered and washed with water. The crude solid was crystallized in ethanol to afford the corresponding pure product (4) and used for the further reaction without purification.

\subsection{Typical Experimental Procedure for the Synthesis of Sulfamethaoxazole Incorporated Substituted 4-Thiazolidinone Hybrid ( $7 a$ )}

The mixture of appropriate 4-amino- $N$-(5-methylisoxazol-3-yl)benzenesulfonamide (4) (1 mmol), benzaldehydes (5a) (1 mmol) and mercapto acetic acid (6) $(1.2 \mathrm{mmol})$ in toluene (5 mL) was placed in a round bottom flask. The mixture was refluxed at $120^{\circ} \mathrm{C}$ for an appropriate time until the completion of the reaction. The progress of the reaction was monitored by TLC using ethyl acetate: hexane as a solvent system. The reaction mixture was quenched with crushed ice and extracted with ethyl acetate $(2 \times 15 \mathrm{~mL})$. The organic extracts were washed with brine solution $(2 \times 15 \mathrm{~mL})$ and dried over anhydrous sodium sulphate. The solvent was evaporated under reduced pressure to afford the corresponding crude compounds. The obtained crude compounds were recrystallized using ethanol.

\subsubsection{N-(5-methylisoxazol-3-yl)-4-(4-oxo-2-phenylthiazolidin-3-yl)benzenesulfonamide (7a)}

Compound 7a was obtained from the cyclocondensation reaction between 4, 5a, and 6 for 12 h. White solid; m.p.: $220-222{ }^{\circ} \mathrm{C}$; Yield: 84\%; ${ }^{1} \mathrm{H}$ NMR (400 MHz, DMSO- $d_{6}, \delta$ ppm): 9.49 (s, $\left.1 \mathrm{H}, \mathrm{NH}\right)$, 8.05-8.04 (m, 2H, Ar-H), 7.33-7.28 (m, 4H, Ar-H), 7.25-7.22 (m, 3H, Ar-H), 6.71 (s, 1H, S-CH-N), $5.88(\mathrm{~s}, 1 \mathrm{H},-\mathrm{C}=\mathrm{CH}), 3.76\left(\mathrm{~d}, 1 \mathrm{H}, \mathrm{CH}_{2}, \mathrm{~J}=12 \mathrm{~Hz}\right), 3.72\left(\mathrm{~d}, 1 \mathrm{H}, \mathrm{CH}_{2}, J=12 \mathrm{~Hz}\right)$ and $2.39\left(\mathrm{~s}, 3 \mathrm{H},-\mathrm{CH}_{3}\right)$; ${ }^{13} \mathrm{C}$ NMR (100 MHz, DMSO- $d_{6}, \delta$ ppm): 179.27, 169.78, 152.98, 143.54, 140.31, 136.81, 132.99, 131.16, 131.08, 129.61, 127.78, 99.76, 68.44, 33.04 and 14.53; HRMS (ESI-qTOF): Calcd. for $\mathrm{C}_{19} \mathrm{H}_{18} \mathrm{~N}_{3} \mathrm{O}_{4} \mathrm{~S}_{2}$ $[\mathrm{M}+\mathrm{H}]^{+}, 416.2166$ : found: 416.2147 .

\subsubsection{N-(5-methylisoxazol-3-yl)-4-(4-oxo-2-(p-tolyl)thiazolidin-3-yl)benzenesulfonamide (7b)}

Compound $7 \mathbf{b}$ was obtained from the cyclocondensation reaction between 4 , 5b, and 6 for $12 \mathrm{~h}$. White solid; m.p.: $234-236{ }^{\circ} \mathrm{C}$; Yield: $82 \%$; ${ }^{1} \mathrm{H}$ NMR (400 MHz, DMSO- $d_{6}, \delta$ ppm): $9.68(\mathrm{~s}, 1 \mathrm{H}, \mathrm{NH})$, 8.10-8.09 (m, 2H, Ar-H), 7.33-7.31 (m, 2H, Ar-H), 7.27-25 (m, 2H, Ar-H), 7.19-7.18 (m, 2H, Ar-H), $6.68(\mathrm{~s}, 1 \mathrm{H}, \mathrm{S}-\mathrm{CH}-\mathrm{N}), 5.88(\mathrm{~s}, 1 \mathrm{H},-\mathrm{C}=\mathrm{CH}), 3.81\left(\mathrm{~d}, 1 \mathrm{H}, \mathrm{CH}_{2}, J=12 \mathrm{~Hz}\right), 3.77\left(\mathrm{~d}, 1 \mathrm{H}, \mathrm{CH}_{2}, J=12 \mathrm{~Hz}\right)$, $2.43\left(\mathrm{~s}, 3 \mathrm{H},-\mathrm{CH}_{3}\right)$ and $2.37\left(\mathrm{~s}, 3 \mathrm{H},-\mathrm{CH}_{3}\right) ;{ }^{13} \mathrm{C} \mathrm{NMR}\left(100 \mathrm{MHz}, \mathrm{DMSO}-d_{6}, \delta \mathrm{ppm}\right): 173.14,169.97,152.76$, 141.98, 137.28, 133.23, 130.01, 129.47, 128.55, 128.49, 128.23, 100.11, 66.62, 36.89, 24.97 and 12.16; HRMS (ESI-qTOF): Calcd. for $\mathrm{C}_{20} \mathrm{H}_{20} \mathrm{~N}_{3} \mathrm{O}_{4} \mathrm{~S}_{2}[\mathrm{M}+\mathrm{H}]^{+}, 430.0875$ : found: 430.0893 . 
3.3.3. 4-(2-(4-methoxyphenyl)-4-oxothiazolidin-3-yl)-N-(5-methylisoxazol-3-yl)benzenesulfonamide (7c)

Compound 7c was obtained from the cyclocondensation reaction between $4,5 \mathrm{c}$, and 6 for $12 \mathrm{~h}$. White solid; m.p.: $242-234{ }^{\circ} \mathrm{C}$; Yield: $84 \%{ }^{1}{ }^{1} \mathrm{H}$ NMR $\left(400 \mathrm{MHz}, \mathrm{DMSO}-d_{6}, \delta\right.$ ppm): $9.42(\mathrm{~s}, 1 \mathrm{H}, \mathrm{NH})$, 8.02-8.01 (m, 2H, Ar-H), 7.25-7.24 (m, 2H, Ar-H), 7.21-7.20 (m, 2H, Ar-H), 6.85-6.84 (m, 2H, Ar-H), $6.56(\mathrm{~s}, 1 \mathrm{H}, \mathrm{S}-\mathrm{CH}-\mathrm{N}), 5.80(\mathrm{~s}, 1 \mathrm{H},-\mathrm{C}=\mathrm{CH}), 3.79\left(\mathrm{~s}, 1 \mathrm{H},-\mathrm{OCH}_{3}\right), 3.72\left(\mathrm{~d}, 1 \mathrm{H}, \mathrm{CH}_{2}, J=12 \mathrm{~Hz}\right), 3.69(\mathrm{~d}, 1 \mathrm{H}$, $\mathrm{CH}_{2}, J=12 \mathrm{~Hz}$ ) and $2.35\left(\mathrm{~s}, 3 \mathrm{H},-\mathrm{CH}_{3}\right) ;{ }^{13} \mathrm{C}$ NMR $\left(100 \mathrm{MHz}, \mathrm{DMSO}-d_{6}, \delta \mathrm{ppm}\right): 178.60,168.20,157.10$, 143.22, 139.70, 132.71, 130.85, 129.58, 129.37, 127.39, 125.19, 102.19, 66.07, 52.53, 32.06 and 13.08; HRMS (ESI-qTOF): Calcd. for $\mathrm{C}_{20} \mathrm{H}_{20} \mathrm{~N}_{3} \mathrm{O}_{5} \mathrm{~S}_{2}[\mathrm{M}+\mathrm{H}]^{+}, 446.0521$ : found: 446.0546 .

3.3.4. 4-(2-(4-fluorophenyl)-4-oxothiazolidin-3-yl)- $N$-(5-methylisoxazol-3-yl)benzenesulfonamide (7d)

Compound $\mathbf{7 d}$ was obtained from the cyclocondensation reaction between $\mathbf{4}, \mathbf{5 d}$, and $\mathbf{6}$ for $12 \mathrm{~h}$. Yellow solid; m.p.: $216-218{ }^{\circ} \mathrm{C}$; Yield: $80 \%$; ${ }^{1} \mathrm{H}$ NMR (400 MHz, DMSO- $d_{6}, \delta$ ppm): $9.54(\mathrm{~s}, 1 \mathrm{H}, \mathrm{NH})$, 8.02-8.01 (m, 2H, Ar-H), 7.33-7.32 (m, 2H, Ar-H), 7.27-7.25 (m, 2H, Ar-H), 7.07-7.04 (m, 2H, Ar-H), $6.60(\mathrm{~s}, 1 \mathrm{H}, \mathrm{S}-\mathrm{CH}-\mathrm{N}), 6.18(\mathrm{~s}, 1 \mathrm{H},-\mathrm{C}=\mathrm{CH}), 3.77\left(\mathrm{~d}, 1 \mathrm{H}, \mathrm{CH}_{2}, J=12 \mathrm{~Hz}\right), 3.73\left(\mathrm{~d}, 1 \mathrm{H}, \mathrm{CH}_{2}, J=12 \mathrm{~Hz}\right)$ and $2.39\left(\mathrm{~s}, 3 \mathrm{H},-\mathrm{CH}_{3}\right) ;{ }^{13} \mathrm{C}$ NMR $\left(100 \mathrm{MHz}\right.$, DMSO- $\left.d_{6}, \delta \mathrm{ppm}\right): 176.31,168.22,161.79,160.24,154.29,143.81$, 143.36, 129.57, 129.52, 129.36, 127.42, 125.69, 115.63, 105.09, 68.12, 33.58 and 12.70; HRMS (ESI-qTOF): Calcd. for $\mathrm{C}_{19} \mathrm{H}_{17} \mathrm{FN}_{3} \mathrm{O}_{4} \mathrm{~S}_{2}[\mathrm{M}+\mathrm{H}]^{+}$, 434.0858: found: 434.0893 .

3.3.5. 4-(2-(2-chlorophenyl)-4-oxothiazolidin-3-yl)-N-(5-methylisoxazol-3-yl)benzenesulfonamide (7e)

Compound 7e was obtained from the cyclocondensation reaction between $4,5 e$, and 6 for $12 \mathrm{~h}$. White solid; m.p.: $240-242{ }^{\circ} \mathrm{C}$; Yield: $84 \% ;{ }^{1} \mathrm{H}$ NMR (400 MHz, DMSO- $d_{6}, \delta$ ppm): $9.62(\mathrm{~s}, 1 \mathrm{H}, \mathrm{NH})$, 8.27-8.26 (m, 2H, Ar-H), 7.48-7.46 (m, 3H, Ar-H), 7.37-7.31 (m, 3H, Ar-H), 6.87 (s, 1H, S-CH-N), $6.35(\mathrm{~s}, 1 \mathrm{H},-\mathrm{C}=\mathrm{CH}), 3.92\left(\mathrm{~d}, 1 \mathrm{H}, \mathrm{CH}_{2}, J=12 \mathrm{~Hz}\right), 3.90\left(\mathrm{~d}, 1 \mathrm{H}, \mathrm{CH}_{2}, J=12 \mathrm{~Hz}\right)$ and $2.23\left(\mathrm{~s}, 3 \mathrm{H},-\mathrm{CH}_{3}\right)$; ${ }^{13} \mathrm{C}$ NMR (100 MHz, DMSO- $d_{6}, \delta$ ppm): 171.64, 167.47, 156.19, 143.33, 141.16, 138.58, 135.94, 132.27, 130.80, 129.46, 127.47, 125.43, 122.06, 101.90, 65.58, 35.18 and 14.01; HRMS (ESI-qTOF): Calcd. for $\mathrm{C}_{19} \mathrm{H}_{17} \mathrm{ClN}_{3} \mathrm{O}_{4} \mathrm{~S}_{2}[\mathrm{M}+\mathrm{H}]^{+}, 450.0786$ : found: 450.0796 .

3.3.6. 4-(2-(3-chlorophenyl)-4-oxothiazolidin-3-yl)-N-(5-methylisoxazol-3-yl)benzenesulfonamide (7f)

Compound $\mathbf{7 f}$ was obtained from the cyclocondensation reaction between $\mathbf{4}, \mathbf{5 f}$, and $\mathbf{6}$ for $12 \mathrm{~h}$. White solid; m.p.: $228-230{ }^{\circ} \mathrm{C}$; Yield: $78 \% ;{ }^{1} \mathrm{H}$ NMR (400 MHz, DMSO- $d_{6}, \delta$ ppm): $9.56(\mathrm{~s}, 1 \mathrm{H}, \mathrm{NH})$, 8.04-8.02 (m, 2H, Ar-H), 7.35 (s, 1H, Ar-H), 7.27-7.25 (m, 4H, Ar-H), 7.14-7.11 (m, 1H, Ar-H), 6.65 (s, 1H, S-CH-N), $6.46(\mathrm{~s}, 1 \mathrm{H},-\mathrm{C}=\mathrm{CH}), 3.78\left(\mathrm{~d}, 1 \mathrm{H}, \mathrm{CH}_{2}, J=12 \mathrm{~Hz}\right), 3.74\left(\mathrm{~d}, 1 \mathrm{H}, \mathrm{CH}_{2}, J=12 \mathrm{~Hz}\right)$ and $2.40(\mathrm{~s}, 3 \mathrm{H}$, $\left.-\mathrm{CH}_{3}\right) ;{ }^{13} \mathrm{C}$ NMR $\left(100 \mathrm{MHz}\right.$, DMSO- $d_{6}, \delta$ ppm): 179.77, 167.82, 156.82, 143.99, 143.52, 133.04, 131.60, 129.69, 129.53, 127.56, 125.86, 124.57, 122.12, 103.76, 68.63, 34.98 and 13.79; HRMS (ESI-qTOF): Calcd. for $\mathrm{C}_{19} \mathrm{H}_{17} \mathrm{ClN}_{3} \mathrm{O}_{4} \mathrm{~S}_{2}[\mathrm{M}+\mathrm{H}]^{+}, 450.1372$ : found: 450.1396 .

3.3.7. 4-(2-(4-chlorophenyl)-4-oxothiazolidin-3-yl)-N-(5-methylisoxazol-3-yl)benzenesulfonamide (7g)

Compound $7 \mathrm{~g}$ was obtained from the cyclocondensation reaction between $4,5 \mathrm{~g}$, and 6 for $12 \mathrm{~h}$. White solid; m.p.: $245-247{ }^{\circ} \mathrm{C}$; Yield: $80 \% ;{ }^{1} \mathrm{H}$ NMR $\left(400 \mathrm{MHz}, \mathrm{DMSO}-d_{6}, \delta \mathrm{ppm}\right): 9.76(\mathrm{~s}, 1 \mathrm{H}, \mathrm{NH})$, 8.02-8.01 (m, 2H, Ar-H), 7.33-7.32 (m, 2H, Ar-H), 7.24-7.23 (m, 2H, Ar-H), 7.19-7.17 (m, 2H, Ar-H), $6.60(\mathrm{~s}, 1 \mathrm{H}, \mathrm{S}-\mathrm{CH}-\mathrm{N}), 6.43(\mathrm{~s}, 1 \mathrm{H},-\mathrm{C}=\mathrm{CH}), 3.76\left(\mathrm{~d}, 1 \mathrm{H}, \mathrm{CH}_{2}, J=12 \mathrm{~Hz}\right), 3.73\left(\mathrm{~d}, 1 \mathrm{H}, \mathrm{CH}_{2}, J=12 \mathrm{~Hz}\right)$ and $2.38\left(\mathrm{~s}, 3 \mathrm{H},-\mathrm{CH}_{3}\right) ;{ }^{13} \mathrm{C}$ NMR (100 MHz, DMSO- $\left.d_{6}, \delta \mathrm{ppm}\right): 182.76,165.85,157.74,141.75,139.99$, 128.90, 128.41, 127.88, 124.50, 124.32, 124.19, 99.96, 66.56, 31.80 and 14.15; HRMS (ESI-qTOF): Calcd. for $\mathrm{C}_{19} \mathrm{H}_{17} \mathrm{ClN}_{3} \mathrm{O}_{4} \mathrm{~S}_{2}[\mathrm{M}+\mathrm{H}]^{+}, 450.0042$ : found: 450.0025 .

3.3.8. 4-(2-(4-bromophenyl)-4-oxothiazolidin-3-yl)-N-(5-methylisoxazol-3-yl)benzenesulfonamide (7h)

Compound 7h was obtained from the cyclocondensation reaction between $4,5 \mathrm{~h}$, and 6 for $12 \mathrm{~h}$. Red solid; m.p.: $234-236{ }^{\circ} \mathrm{C}$; Yield: $80 \% ;{ }^{1} \mathrm{H}$ NMR (400 MHz, DMSO- $d_{6}, \delta$ ppm): $9.64(\mathrm{~s}, 1 \mathrm{H}, \mathrm{NH})$, 8.10-8.09 (m, 2H, Ar-H), 7.48-7.46 (m, 3H, Ar-H), 7.24-7.22 (m, 2H, Ar-H), 7.17-7.15 (m, 2H, Ar-H), 
$6.63(\mathrm{~s}, 1 \mathrm{H}, \mathrm{S}-\mathrm{CH}-\mathrm{N}), 6.49(\mathrm{~s}, 1 \mathrm{H},-\mathrm{C}=\mathrm{CH}), 3.76\left(\mathrm{~d}, 1 \mathrm{H}, \mathrm{CH}_{2}, J=12 \mathrm{~Hz}\right), 3.72\left(\mathrm{~d}, 1 \mathrm{H}, \mathrm{CH}_{2}, J=12 \mathrm{~Hz}\right)$ and $2.39\left(\mathrm{~s}, 3 \mathrm{H},-\mathrm{CH}_{3}\right) ;{ }^{13} \mathrm{C}$ NMR (100 MHz, DMSO- $\left.d_{6}, \delta \mathrm{ppm}\right): 175.95,167.58,156.57,143.74,143.29$, 135.76, 129.44, 129.19, 125.61, 124.31, 123.96, 97.85, 65.68, 34.06 and 12.32; HRMS (ESI-qTOF): Calcd. for $\mathrm{C}_{19} \mathrm{H}_{17} \mathrm{BrN}_{3} \mathrm{O}_{4} \mathrm{~S}_{2}[\mathrm{M}+\mathrm{H}]^{+}$, 495.1038: found: 495.1071 .

3.3.9. N-(5-methylisoxazol-3-yl)-4-(4-oxo-2-(4-(trifluoromethyl)phenyl)thiazolidin-3-yl) benzenesulfonamide (7i)

Compound $7 \mathbf{i}$ was obtained from the cyclocondensation reaction between $4,5 i$, and 6 for $12 \mathrm{~h}$. White solid; m.p.: $225-227{ }^{\circ} \mathrm{C}$; Yield: $80 \%$; ${ }^{1} \mathrm{H}$ NMR $\left(400 \mathrm{MHz}, \mathrm{DMSO}-d_{6}, \delta \mathrm{ppm}\right): 9.33(\mathrm{~s}, 1 \mathrm{H}, \mathrm{NH})$, 8.04-8.02 (m, 2H, Ar-H), 7.52-751 (m, 2H, Ar-H), 7.25-7.23 (m, 2H, Ar-H), 6.70 (s, 1H, S-CH-N), $6.06(\mathrm{~s}, 1 \mathrm{H},-\mathrm{C}=\mathrm{CH}), 3.75\left(\mathrm{~d}, 1 \mathrm{H}, \mathrm{CH}_{2}, J=12 \mathrm{~Hz}\right), 3.71\left(\mathrm{~d}, 1 \mathrm{H}, \mathrm{CH}_{2}, J=12 \mathrm{~Hz}\right)$ and $2.36(\mathrm{~s}, 3 \mathrm{H}$, $\left.-\mathrm{CH}_{3}\right) ;{ }^{13} \mathrm{C}$ NMR $\left(100 \mathrm{MHz}\right.$, DMSO- $d_{6}, \delta$ ppm): $178.60,165.55,158.09,142.35,139.95,135.99,135.88$, 131.22, 130.49, 130.23, 128.74, 128.05, 98.29, 66.37, 34.75 and 12.43; HRMS (ESI-qTOF): Calcd. for $\mathrm{C}_{20} \mathrm{H}_{17} \mathrm{~F}_{3} \mathrm{~N}_{3} \mathrm{O}_{4} \mathrm{~S}_{2}[\mathrm{M}+\mathrm{H}]^{+}, 484.0728$ found: 484.0756 .

3.3.10. $\mathrm{N}$-(5-methylisoxazol-3-yl)-4-(2-(4-nitrophenyl)-4-oxothiazolidin-3-yl)benzenesulfonamide (7j)

Compound $7 \mathbf{j}$ was obtained from the cyclocondensation reaction between $4,5 \mathbf{j}$, and 6 for $12 \mathrm{~h}$. Yellow solid; m.p.: $246-248{ }^{\circ} \mathrm{C}$; Yield: $74 \% ;{ }^{1} \mathrm{H}$ NMR (400 MHz, DMSO- $d_{6}, \delta$ ppm): $9.64(\mathrm{~s}, 1 \mathrm{H}, \mathrm{NH})$, 8.23-8.21 (m, 2H, Ar-H), 8.03-8.01 (m, 2H, Ar-H), 7.55-7.53 (m, 2H, Ar-H), 7.35-7.34 (m, 2H, Ar-H), $6.71(\mathrm{~s}, 1 \mathrm{H}, \mathrm{S}-\mathrm{CH}-\mathrm{N}), 6.15(\mathrm{~s}, 1 \mathrm{H},-\mathrm{C}=\mathrm{CH}), 3.78\left(\mathrm{~d}, 1 \mathrm{H}, \mathrm{CH}_{2}, J=12 \mathrm{~Hz}\right), 3.75\left(\mathrm{~d}, 1 \mathrm{H}, \mathrm{CH}_{2}, J=12 \mathrm{~Hz}\right)$ and $2.40\left(\mathrm{~s}, 3 \mathrm{H},-\mathrm{CH}_{3}\right) ;{ }^{13} \mathrm{C}$ NMR $\left(100 \mathrm{MHz}, \mathrm{DMSO}-d_{6}, \delta \mathrm{ppm}\right): 179.08,165.76,158.84,141.54,139.90$, 136.65, 134.01, 133.96, 130.38, 128.27, 127.80, 99.96, 67.36, 34.90 and 14.60; HRMS (ESI-qTOF): Calcd. for $\mathrm{C}_{19} \mathrm{H}_{17} \mathrm{~N}_{4} \mathrm{O}_{6} \mathrm{~S}_{2}[\mathrm{M}+\mathrm{H}]^{+}, 461.0075$ : found: 461.0099 .

3.3.11. 4-(2-(2,6-difluorophenyl)-4-oxothiazolidin-3-yl)-N-(5-methylisoxazol-3-yl) benzenesulfonamide $(7 \mathbf{k})$

Compound 7k was obtained from the cyclocondensation reaction between $4,5 k$, and 6 for $12 \mathrm{~h}$. White solid; m.p.: $224-226{ }^{\circ} \mathrm{C}$; Yield: $81 \% ;{ }^{1} \mathrm{H}$ NMR $\left(400 \mathrm{MHz}, \mathrm{DMSO}-d_{6}, \delta\right.$ ppm): $9.50(\mathrm{~s}, 1 \mathrm{H}, \mathrm{NH})$, 8.03-8.01 (m, 2H, Ar-H), 7.29-7.27 (m, 2H, Ar-H), 7.22.7.20 (m, 2H, Ar-H), 7.10-7.09 (m, 2H, Ar-H), $6.95(\mathrm{~s}, 1 \mathrm{H}, \mathrm{S}-\mathrm{CH}-\mathrm{N}), 6.45(\mathrm{~s}, 1 \mathrm{H},-\mathrm{C}=\mathrm{CH}), 3.85\left(\mathrm{~d}, 1 \mathrm{H}, \mathrm{CH}_{2}, J=12 \mathrm{~Hz}\right), 3.82\left(\mathrm{~d}, 1 \mathrm{H}, \mathrm{CH}_{2}, J=12 \mathrm{~Hz}\right)$ and $2.38\left(\mathrm{~s}, 3 \mathrm{H},-\mathrm{CH}_{3}\right) ;{ }^{13} \mathrm{C}$ NMR (100 MHz, DMSO- $\left.d_{6}, \delta \mathrm{ppm}\right): 174.75,166.33,156.87,141.55,140.04$, 128.82, 128.28, 126.03, 124.64, 123.90, 122.60, 99.67, 67.49, 36.45 and 12.62; HRMS (ESI-qTOF): Calcd. for $\mathrm{C}_{19} \mathrm{H}_{16} \mathrm{~F}_{2} \mathrm{~N}_{3} \mathrm{O}_{4} \mathrm{~S}_{2}[\mathrm{M}+\mathrm{H}]^{+}$, 452.1434: found: 452.1481

3.3.12. 4-(2-(2,6-dichlorophenyl)-4-oxothiazolidin-3-yl)- $N$-(5-methylisoxazol-3-yl)benzenesulfonamide (7l)

Compound 71 was obtained from the cyclocondensation reaction between 4, 51, and 6 for $12 \mathrm{~h}$. Yellow solid; m.p.: $218-220{ }^{\circ} \mathrm{C}$; Yield: $80 \% ;{ }^{1} \mathrm{H}$ NMR $\left(400 \mathrm{MHz}, \mathrm{DMSO}-d_{6}, \delta \mathrm{ppm}\right): 9.30(\mathrm{~s}, 1 \mathrm{H}$, $\mathrm{NH}), 8.20$ (s. 1H, Ar-H), 8.12-8.11 (m, 2H, Ar-H), 8.01-8.00 (m, 2H, Ar-H), 7.63-7.62 (m, 2H, Ar-H), 7.54-7.51 (m, 2H, Ar-H), 7.31-7.26 (m, 2H, Ar-H), $6.71(\mathrm{~s}, 1 \mathrm{H}, \mathrm{S}-\mathrm{CH}-\mathrm{N}), 6.06(\mathrm{~s}, 1 \mathrm{H},-\mathrm{C}=\mathrm{CH}), 3.75(\mathrm{~d}, 1 \mathrm{H}$, $\left.\mathrm{CH}_{2}, J=12 \mathrm{~Hz}\right), 3.71\left(\mathrm{~d}, 1 \mathrm{H}, \mathrm{CH}_{2}, J=12 \mathrm{~Hz}\right)$ and $2.39\left(\mathrm{~s}, 3 \mathrm{H},-\mathrm{CH}_{3}\right) ;{ }^{13} \mathrm{C}$ NMR $\left(100 \mathrm{MHz}, \mathrm{DMSO}-d_{6}\right.$, $\delta$ ppm): 174.10, 165.46, 155.58, 144.34, 139.34, 130.13, 129.91, 129.82, 127.96, 127.53, 123.76, 123.48, 123.11, 100.51, 65.04, 35.50 and 14.70; HRMS (ESI-qTOF): Calcd. for $\mathrm{C}_{19} \mathrm{H}_{16} \mathrm{Cl}_{2} \mathrm{~N}_{3} \mathrm{O}_{4} \mathrm{~S}_{2}[\mathrm{M}+\mathrm{H}]^{+}, 485.2672$ : found: 485.2649 .

\section{Conclusions}

In conclusion, the synthesis of sulfamethaoxazole incorporated 4-thiazolidinone hybrids (7a-1) was carried out and their antitubercular activity against $M$. Bovis BCG and MTB H37Ra strains were determined. Among all the tested compounds, $\mathbf{7 d}, \mathbf{7 g}, \mathbf{7 i}, \mathbf{7 k}$, and $7 \mathbf{l}$ were identified as the most active compounds with activity $\mathrm{IC}_{90}$ range $0.22-0.057$ against $M$. bovis $B C G$ strain and $0.43-5.31 \mu \mathrm{g} / \mathrm{mL}$ against 
MTB H37Ra strain. The most potent compounds displayed lower cytotoxicity against MCF-7, HCT 116 and A549 cell line using MTT assay, suggesting that these molecules possess highly pharmacodynamic properties. The most active compounds $\mathbf{7 d}, \mathbf{7 g}, \mathbf{7 i}, \mathbf{7 k}$, and $\mathbf{7 l}$ exhibited a higher selectivity index $>10$ against MCF-7, HCT 116 and A549 which indicated that they act as prominent antitubercular agents. Thus, this suggests that the compounds from the present series $\mathbf{7 d}, \mathbf{7 g}, \mathbf{7 i}, 7 \mathbf{k}$, and $7 \mathbf{l}$ can be further optimized and developed as lead molecules.

Supplementary Materials: Supplementary Materials are available online. Experimental section, biological assays, ${ }^{1} \mathrm{H}$ NMR, ${ }^{13} \mathrm{C}$ NMR and HRMS spectra of all synthesized compounds.

Author Contributions: M.A.B., M.A.A.-O., and A.A.K., conceived and designed the experiments; M.A.B. performed chemical synthesis and purifications. A.M.N., performed biological assays (antimycobacterial, cytotoxicity and antibacterial). M.A.B. wrote the paper. All authors have read and agreed to the published version of the manuscript.

Funding: This work was supported by the Deanship of Scientific Research at King Saud University (Research group no. RG 1435-006).

Acknowledgments: The authors would like to extend their sincere appreciation to the Deanship of Scientific Research at King Saud University for funding this research group no. (RG 1435-006).

Conflicts of Interest: The authors declare that they have no known competing financial interests or personal relationships that could have appeared to influence the work reported in this paper.

\section{References}

1. Dye, C.; Williams, B.G. The Population Dynamics and Control of Tuberculosis. Science 2010, 328, $856-861$. [CrossRef] [PubMed]

2. Zumla, A.; Nahid, P.; Cole, S.T. Advances in the development of new tuberculosis drugs and treatment regimens. Nat. Rev. Drug. Discov. 2013, 5, 388-404. [CrossRef] [PubMed]

3. Zumla, A.I.; Gillespie, S.H.; Hoelscher, M.; Philips, P.P.; Cole, S.T.; Abubakar, I.; McHugh, T.D.; Schito, M.; Maeurer, M.; Nunn, A.J. New antituberculosis drugs, regimens, and adjunct therapies: Needs, advances, and future prospects. Lancet Infect. Dis. 2014, 4, 327-340. [CrossRef]

4. Global Tuberculosis Control: WHO Report. 2019. Available online: https://www.who.int/tb/publications/ global_report/en/ (accessed on 25 July 2020).

5. Lugosi, L. Theoretical and methodological aspects of BCG vaccine from the discovery of Calmette and Guerin to molecular biology. A review. Tuber. Lung Dis. 1992, 73, 252-261. [CrossRef]

6. Udwadia, Z.F.; Amale, R.A.; Ajbani, K.K.; Rodrigues, C. Totally drug-resistant tuberculosis in India. Clin. Infect. Dis. 2012, 54, 579-581. [CrossRef]

7. Butler, M.S.; Blaskovich, M.A.; Cooper, M.A. Antibiotics in the clinical pipeline in 2013. J. Antibiot (Tokyo) 2013, 66, 571-591. [CrossRef]

8. Diacon, A.H.; Donald, P.R.; Pym, A.; Grobusch, M.; Patientia, R.F.; Mahanyele, R.; Bantubani, N.; Narasimooloo, R.; De Marez, T.; van Heeswijk, R.R. Andomized pilot trial of eight weeks of bedaquiline (TMC207) treatment for multidrug-resistant tuberculosis: Long-term outcome, tolerability, and effect on emergence of drug resistance. Antimicrob. Agents Chemother. 2012, 56, 3271-3276. [CrossRef]

9. Gouvea, F.A.; Vasconcellos, G.A.; Berwaldt, A.C.P.S.; Neto, G.; Fischer, R.P.; Sakata, W.P.; Almeida, W.P.; Cunico, W 2-Aryl-3-(2-morpholinoethyl)thiazolidin-4-ones: Synthesis, anti-inflammatory in vivo, cytotoxicity in vitro and molecular docking studies. Eur. J. Med. Chem. 2016, 118, 259-265. [CrossRef]

10. Monte, C.D.; Carradori, S.; Bizzarri, B.; Bolasco, A.; Caprara, F.; Mollica, A.; Rivanera, D.; Mari, E.; Zicari, A.; Akdemir, A. Anti-Candida activity and cytotoxicity of a large library of new N-substituted1,3-thiazolidin-4-onederivatives. Eur. J. Med. Chem. 2016, 107, 82-96. [CrossRef]

11. Rane, R.A.; Sahu, N.U.; Shah, C.P. Synthesis and antibiofilm activity of marine natural product-based 4-thiazolidinones derivatives. Bioorg. Med. Chem. Lett. 2012, 22, 7131-7134. [CrossRef]

12. Zhang, X.; Li, X.; Li, D.; Qua, G.; Wang, J.; Loiseau, P.M.; Fan, X. Ionic liquid mediated and promoted eco-friendly preparation of thiazolidinone and pyrimidine nucleoside-thiazolidinone hybrids and their antiparasitic activities. Bioorg. Med. Chem. Lett. 2009, 19, 6280-6283. [CrossRef] [PubMed]

13. Onen-Bayram, F.E.; Buran, K.; Durmaz, I.; Berk, B.; Cetin-Atalay, R. 3-Propionyl-thiazolidine-4-carboxylic acid ethyl esters: A family of antiproliferative thiazolidines. Med. Chem. Commun. 2015, 6, 90-93. [CrossRef] 
14. Barrec, M.L.; Chimirri, A.; De Luca, L.; Monforte, A.M.; Monforte, P.; Rao, A.; Zappala, M.; Balzarini, J.; De Clercq, E.; Pannecouque, C.; et al. Discovery of 2,3-diaryl-1,3-thiazolidin-4-ones as potentanti-HIV-1 agents. Bioorg. Med. Chem. Lett. 2001, 11, 1793-1796. [CrossRef]

15. Ottana, R.; Maccari, R.; Giglio, M.; Del Corso, A.; Cappiello, M.; Mura, U.; Cosconati, S.; Marinelli, L.; Novellino, E.; Sartini, S.; et al. Identification of 5-arylidene-4 thiazolidinone derivatives endowed with dual activity as aldose reductase inhibitors and antioxidant agents for the treatment of diabetic complications. Eur. J. Med. Chem. 2011, 46, 2797-2806. [CrossRef] [PubMed]

16. Panico, A.M.; Vicini, P.; Geronikaki, A.; Incerti, M.; Cardile, V.; Crasci, L.; Messina, R.; Ronsisvalle, S. Heteroarylimino-4-thiazolidinones as inhibitors of cartilage degradation. Bioorg. Chem. 2011, 39, 48-52. [CrossRef] [PubMed]

17. Wrobel, J.; Jette, J.; Kao, W.; Rogers, J.; Di, L.; Chi, J.; Perez, M.C.; Chen, G.C.; Shen, E.S. 5-Alkylated thiazolidinones as follicle-stimulating hormone (FSH) receptor agonists. Bioorg. Med. Chem. 2006, 14, 5729-5741. [CrossRef] [PubMed]

18. Cutshall, N.S.; O’Day, C.; Prezhdo, M. Rhodanine derivatives as inhibitors of JSP-1. Bioorg. Med. Chem. Lett. 2005, 15, 3374-3379. [CrossRef] [PubMed]

19. Joshi, P.; Anderson, C.; Binch, H.; Hadida, S.; Yoo, S.; Bergeron, D.; Decker, C.; terHaar, E.; Moore, J.; Garcia-Guzman, M.; et al. Identification of potent CNS-penetrant thiazolidinones as novel CGRP receptor antagonists. Bioorg. Med. Chem. Lett. 2014, 24, 845-849. [CrossRef] [PubMed]

20. Chen, S.; Chen, L.; Le, N.T.; Zhao, C.; Sidduri, A.; Lou, J.P.; Michoud, C.; Portland, L.; Jackson, N.; Liu, J.J.; et al. Synthesis and activity of quinolinyl-methylene-thiazolinones as potent and selective cyclin-dependent kinase 1 inhibitors. Bioorg. Med. Chem. Lett. 2007, 17, 2134-2138. [CrossRef]

21. Unsal-Tan, O.; Ozadali, K.; Piskin, K.; Balkan, A. Molecular modeling, synthesis and screening of some new 4-thiazolidinone derivatives with promising selective COX-2 inhibitory activity. Eur. J. Med. Chem. 2012, 57, 59-64. [CrossRef]

22. Raza, S.; Srivastava, S.P.; Srivastava, D.S.; Srivastava, A.K.; Haq, W.; Katt, S.B. Thiazolidin-4-one and thiazinan-4-one derivatives analogous to rosiglitazone as potential antihyperglycemic and antidyslipidemic agents. Eur. J. Med. Chem. 2013, 63, 611-620. [CrossRef] [PubMed]

23. Kucukguzel, S.G.; Oruc, E.E.; Rollas, S.; Sahin, F.; Ozbek, A. Synthesis, characterization and biological activity of novel 4-thiazolidinones, 1,3,4-oxadiazoles and some related compounds. Eur. J. Med. Chem. 2002, 37, 197-206. [CrossRef]

24. Jaju, S.; Palkar, M.; Maddi, V.; Ronad, P.K.; Mamledesai, S.; Satyanarayana, D.; Ghatole, M. Synthesis and antimycobacterial activity of a novel series of isonicotinyl hydrazide derivatives. Arch. Pharm. Chem. Life Sci. 2009, 342, 723-731. [CrossRef] [PubMed]

25. Babaoglu, K.; Page, M.A.; Jones, V.C.; McNeil, M.R.; Dong, C.; Naismith, J.H.; Lee, R.E. Novel inhibitors of an emerging target in Mycobacterium tuberculosis; substituted thiazolidinones as inhibitors of dTDP-rhamnose synthesis. Bioorg. Med. Chem. Lett. 2003, 13, 3227-3230. [CrossRef]

26. Parekh, H.H.; Parikh, K.H.; Parikh, A.R. Synthesis of some 4-thiazolidinone derivatives as antitubercular ragents. J. Sci. Islm. Rep. Iran. 2004, 15, 143-148.

27. Aridoss, G.; Amirthaganesan, S.; Kim, M.S.; Kim, J.T.; Jeong, Y.T. Synthesis, spectral and biological evaluation of some new thiazolidinones and thiazoles base dont-3-alkyl-r-2,c-6-diarylpiperidin-4-ones. Eur. J. Med. Chem. 2009, 44, 4199-4210. [CrossRef]

28. Patel, A.B.; Chikhalia, K.H.; Kumari, P. Facile synthesis of benzonitrile/nicotinonitriles baseds-triazines as new potential antimycobacterial agents. Eur. J. Med. Chem. 2014, 79, 57-65. [CrossRef]

29. Ramani, A.V.; Monika, A.; Indira, V.L.; Karyavardhi, G.; Venkatesh, J.; Jeankumar, V.U.; Manjashetty, T.H.; Yogeeswari, P.; Sriram, D. Synthesis of highly potent novel anti-tubercular isoniazid analogues with preliminary pharmacokinetic evaluation. Bioorg. Med. Chem. Lett. 2012, 22, 2764-2767. [CrossRef]

30. More, U.A.; Joshi, S.D.; Aminabhavi, T.M.; Gadad, A.K.; Nadagouda, M.N.; Kulkarni, V.H. Design, synthesis, molecular docking and 3D-QSAR studies of potent inhibitors of enoyl-acyl carrier protein reductase as potential antimycobacterial agents. Eur. J. Med. Chem. 2014, 71, 199-218. [CrossRef]

31. Zhao, J.; Xu, J.; Chen, J.; Wang, X.; He, M. Metal-free oxidative coupling of amines with sodium sulfinates: A mild access to sulfonamides. RSC Adv. 2014, 4, 64698-64701. [CrossRef]

32. Pandya, R.; Murashima, T.; Tedeschi, L.; Barrett, A.G.M. Facile one-pot synthesis of aromatic and heteroaromatic sulfonamides. J. Org. Chem. 2003, 68, 8274-8276. [CrossRef] [PubMed] 
33. El-Mossalamy, E.H. Potentiometric and Spectroscopic Studies of Sulfonamide Azo-Dye Complexes with some Transition Metal Ions and Uranium Portu. Port. Electrochim. Acta 2009, 27, 143-152. [CrossRef]

34. Singhal, A.; Parumala, S.K.R.; Sharma, A.; Peddinti, R.K. Hypervalent iodine mediated synthesis of di-and tri-substituted isoxazoles via [3+2] cycloaddition of nitrile oxides. Tetrahedron Lett. 2015, 57, 719-722. [CrossRef]

35. Murugesan, V.; Makwana, N.; Suryawanshi, R.; Saxena, R.; Tripathi, R.; Paranjape, R.; Kulkarni, S.; Katti, S.B. Rational design and synthesis of novel thiazolidin-4-ones as non-nucleoside HIV-1 reverse transcriptase inhibitors. Bioorg. Med. Chem. 2014, 22, 3159-3170. [CrossRef]

36. Bhat, M.A.; Al-Omar, M.A.; Naglah, A.M.; Khan, A.A. [ $\left.\mathrm{Et}_{3} \mathrm{NH}\right]\left[\mathrm{HSO}_{4}\right]$-mediated efficient synthesis of novel xanthene derivatives and their biological evaluation. J. Saudi Chem. Soc. 2020, 24, 425-433. [CrossRef]

37. Bhat, M.A. Synthesis and anti-mycobacterial activity of new 4-thiazolidinone and 1,3,4-oxadiazole derivatives of isoniazid. Acta Pol. Pharm. 2014, 71, 763-770.

38. Boyle, J.; Otty, S.; Sarojini, V. A Safer and Convenient Synthesis of Sulfathiazole for Undergraduate Organic and Medicinal Chemistry Classes. J. Chem. Educ. 2012, 89, 141-143. [CrossRef]

39. Iona, E.; Pardini, M.; Gagliardi, M.C.; Colone, M.; Stringaro, A.R.; Teloni, R.; Brunori, L.; Nisini, R.; Fattorini, L.; Giannoni, F. Infection of human THP-1 cells with dormant Mycobacterium tuberculosis. Microbes Infect. 2012, 14, 959-967. [CrossRef]

40. Van de Loosdrecht, A.A.; Beelen, R.H.; Ossenkoppele, G.J.; Broekhoven, M.G.; Langenhuijsen, M.M. A tetrazolium-based colorimetric MTT assay to quantitate human monocyte mediated cytotoxicity against leukemic cells from cell lines and patients with acute myeloid. J. Immunol. Methods 1994, 174, 311-320. [CrossRef]

41. Hartkoorn, R.C.; Chandler, B.; Owen, A.; Ward, S.A.; Squire, S.B.; Back, D.J.; Khoo, S.H. Differential drug susceptibility of intracellular and extracellular tuberculosis, and the impact of P-glycoprotein. Tuberculosis 2007, 87, 248-255. [CrossRef]

42. Lipinski, C.A.; Lombardo, L.; Dominy, B.W.; Freeney, P.J. Experimental and computational approaches to estimate solubility and permeability in drug discovery and development settings. Adv. Drug Deliv. Rev. 2001, 46, 3-26. [CrossRef]

43. Molinspiration Chemoinformatics Brastislava, Slovak Republic. 2014. Available online: http://www. molinspiration.com/cgi-bin/properties (accessed on 25 July 2020).

44. Zhao, Y.H.; Abraham, M.H.; Lee, J.; Hersey, A.; Luscombe, N.C.; Beck, G.; Sherborne, B.; Cooper, I. Rate-Limited Steps of Human Oral Absorption and QSAR Studies. Pharm. Res. 2002, 19, 1446-1457. [CrossRef] [PubMed]

45. Drug-Likeness and Molecular Property Prediction. Available online: http://www.molsoft.com/mprop/ (accessed on 25 July 2020).

46. Ertl, P.; Rohde, B.; Selzer, P. Fast Calculation of Molecular Polar Surface Area as a Sum of Fragment-Based Contributions and Its Application to the Prediction of Drug Transport Properties. J. Med. Chem. 2000, 43, 3714-3717. [CrossRef] [PubMed]

47. Bouz, G.; Juhas, M.; Otero, L.P.; Red, C.P.; Jandourek, O.; Konecna, K.; Paterova, P.; Kubicek, V.; Janousek, J.; Dolezal, M.; et al. Substituted N-(Pyrazin-2-yl)benzenesulfonamides; Synthesis, Anti-Infective Evaluation, Cytotoxicity, and In Silico Studies. Molecules 2020, 25, 138. [CrossRef] [PubMed]

48. Tauro, M.; Laghezza, A.; Loiodice, F.; Piemontese, L.; CaraDonna, A.; Capelli, D.; Montanari, R.; Pochetti, G.; Di Pizio, A.; Agamennone, M. Catechol-based matrix metalloproteinase inhibitors with additional anti oxidative activity. J. Enzym. Inhib. Med. Chem. 2016, 31, 25-37. [CrossRef]

49. Ogryzek, M.; Chylewska, A.; Turecka, K.; Lesiak, D.; Krolicka, A.; Banasiuk, R.; Nidzworski, D.; Makowski, M. Coordination chemistry of pyrazine derivatives analogues of PZA: Design, synthesis, characterization and biological activity. RSC Adv. 2016, 6, 52009-52025. [CrossRef]

50. Pedersen, K.S.; Perlepe, P.; Aubrey, M.L.; Woodruff, D.N.; Reyes-Lillo, S.E.; Reinholdt, A.; Voigt, L.; $\mathrm{Li}$, Z.; Borup, K.; Rouzieres, M. Formation of the layered conductive magnet $\mathrm{CrCl}_{2}$ (pyrazine) (2) through redox-active coordination chemistry. Nat. Chem. 2018, 10, 1056-1061. [CrossRef]

Sample Availability: Samples of the compounds are available from the authors. 